\title{
DAMPAK MENINGKATNYA KOMPETENSI DOSEN DAN MOTIVASI BELAJAR TERHADAP PRESTASI BELAJAR MAHASISWA
}

\author{
Muhammad Rizal Syaifuddin ${ }^{1}$, Dhiah Fitrayati ${ }^{2}$ \\ ${ }^{1}$ Universitas Negeri Surabaya, muhammadsyaifuddin16080554039@mhs.unesa.ac.id \\ ${ }^{2}$ Universitas Negeri Surabaya, dhiahfitrayati@unesa.ac.id
}

DOI

https://doi.org/10.26740/jupe.v9n3. p77-83

\section{Article history \\ Received \\ 6 June 2021 \\ Revised \\ 14 June 2021 \\ Accepted}

18 June 2021

\section{How to cite}

Syaifuddin, M.R., \& Fotrayati, D. (2021). Dampak Meningkatnya Kompetensi Dosen dan Motivasi Belajar Terhadap Prestasi Belajar Mahasiswa. Jurnal Pendidikan Ekonomi (JUPE), 9(2), 77-83. https://doi.org/10.26740/jupe.v9n3. p77-83

Kata Kunci: Kompetensi Dosen, Motivasi Belajar, Prestasi Belajar

Keywords: Lecturer Competence, Learning Motivation, Learning Achievement

\section{Corresponding author}

Muhammad Rizal Syaifuddin muhammadsyaifuddin16080554039@ mhs.unesa.ac.id

\begin{abstract}
Abstrak
Tujuan penelitian ini untuk mengetahui pengaruh kompetensi dosen dan motivasi belajar terhadap prestasi belajar mahasiswa pada jurusan pendidikan ekonomi angkatan 2017 Universitas Negeri Surabaya. Penelitian ini merupakan penelitian kuantitatif asosiatif. Responden sebanyak 167 mahasiswa. Hasil menunjukan komptensi dosen dan motivasi belajar berpengaruh posisitf dan signifikan baik secara parsial maupun simultan terhadap prestasi belajar mahasiswa. Kesimpulan dari penelitian ini adalah prestasi belajar yang tinggi dapat diperoleh dengan cara meningkatkan motivasi belajar mahasiswa sendiri sebagai faktor internal serta kompetensi yang dimiliki dosen juga membantu meningkatkan prestasi belajar dari sisi eksternal, sehingga kedua faktor tersebut harapannya dapat membantu mahasiswa mencapai prestasi belajar yang tinggi.
\end{abstract}

Abstract
The purpose of this study was to determine the effect of lecture competence
and learning motivation on the learning achievement of 2017 Economics
Education Department Student at State University of Surabaya. This research
is an associative quantitative research. Respondents were 167 students. The
results of this research indicate lecturer competence and learning motivation
have a positive and significant effect either partially or simultaneously on
student learning. The conclusion of this study is that high learning
achievement can be obtained by increasing the student's own learning
motivation as an internal factor and the competence possessed by the
lecturers also helps improve learning achievement from the external side, so
that the two factors are expected to help students achieve high learning
achievement.

\section{Abstract}

The purpose of this study was to determine the effect of lecture competence and learning motivation on the learning achievement of 2017 Economics Education Department Student at State University of Surabaya. This research is an associative quantitative research. Respondents were 167 students. The results of this research indicate lecturer competence and learning motivation motivation as an internal factor and the competence possessed by the lecturers also helps improve learning achievement from the external side, so achievement. 


\section{PENDAHULUAN}

Perguruan Tinggi merupakan tempat berkembangnya potensi mahasiswa untuk mengembangkan kemampuan ilmu pengetahuan serta membentuk watak peradaban bangsa yang bermartabat dalam rangka mencerdaskan kehidupan bangsa. Idaman Jelita yang meliputi Iman, Cerdas, Jujur, Peduli dan Tangguh yang harus ditanamkan dan ditumbuhkan di civitas akademik Universitas Negeri Surabaya.

Universitas Negeri Surabaya memiliki indikator kinerja yang salah satunya meliputi kompetensi dosen dan prestasi mahasiswa. Kompetensi dosen dinilai dari produktivitas, kualitas dan kuantitas dalam kegiatan akademik. Prestasi mahasiswa dipetakan menjadi bidang non akademik dan akademik. Hasil akhir dari pencapaian mahasiswa selama di perguruan tinggi yakni IPK (Indeks Prestasi Kumulatif), merupakan gambaran tolok ukur keberhasilan mahasiswa selama proses belajar.

Dalam proses pembelajaran terdapat adanya interaksi antar dua subyek yakni dosen yang berfungsi sebagai fasilitator atau transfer ilmu kepada mahasiswa. Menurut Sadirman (2020) dalam teori belajar konstruktivisme, proses belajar dan interksi sosial merupakan suatu ukuran keberhasilan mahasiswa. Prestasi belajar mahasiswa merupakan suatu tolok ukur yang sangat penting bagi lulusan mahasiswa karena dinilai telah berhasil dalam proses belajar selama di perguruan tinggi, yang nantinya akan sangat berguna bagi mahasiswa sebagai salah satu bekal untuk melangkah ke dunia kerja.

Slameto (2010) mengemukakan keberhasilan mahasiswa dalam pencapaian prestasi belajar selama proses belajar mengajar dipengaruhi oleh faktor internal dan eksternal. Salah satu faktor internal yang mempengaruhi prestasi belajar yakni motivasi belajar. Motivasi merupakan sebuah dorongan dalam diri inidividu untuk melakukan sebuah tindakan.

Danim (2010) menjelaskan dosen merupakan faktor eksternal yang berpengaruh pada prestasi belajar mahasiswa yang diukur melalui kompetensi yang dimiliki dosen. Kompetensi dosen merupakan sebuah komitmen berstandar layanan yang diperlukan oleh mahasiswa dalam hal transfer ilmu untuk mencapai visi dan misi perguruan tinggi, salah satu tolok ukurnya yakni prestasi akademik yang dicapai mahasiswa selama proses pembelajaran.

Menurut (Undang-Undang Republik Indonesia Nomor 14 Tahun 2005 Tentang Guru dan Dosen, n.d.), dosen memiliki kompetensi yakni 1)kompetensi pedagogik meliputi kemampuan mengelola pembelajaran 2)kompetensi kepribadian meliputi sikap dan tindakan dosen selama proses pembelajaran berlangsung 3)kompetensi sosial meliputi kemampuan interaksi komunikasi 4)kompetensi profesional yang meliputi penguasaan materi serta menyebarluaskan inovasi dalam bidang ilmu pengetahuan. Dosen dapat mentranformasikan ilmunya kepada mahasiswa dengan kompetensi yang dimilikinya.

Hasil riset Ganyaupfu (2014) bahwa kompetensi dosen serta metode pengajaran yang baik membantu mahasiswa meraih prestasi yang tinggi. Wamala (2013) menyatakan bahwa dosen dengan kompetensi yang baik dapat menjadikan optimal serta efisien pada proses belajar yang bertujuan meningkatnya prestasi belajar. Diperkuat penelitian Mediawati (2010) dan Simamora (2014) dengan hasil kompetensi dosen memiliki pengaruh terhadap prestasi belajar mahasiswa secara signifikan secara parsial.

Muzenda (2013); Astuty (2015) dan Yousef (2018) kompetensi yang dimiliki dosen merupakan faktor yang berpengaruh penting dalam meningkatkan prestasi belajar mahasiswa. Diperkuat oleh Alam (2018) kompetensi dosen menjadi faktor eksternal yang berpengaruh pada prestasi belajar, perlu adanya penambahan faktor internal seperti gaya belajar, motivasi dan fasilitas belajar. Serta sejalan dengan penelitian oleh beberapa ahli seperti Olaitan (2018) dan Gee (2018) bahwa kompetensi yang dimiliki dosen berpengaruh terhadap mahasiswa baik dari sisi kinerja mahasiswa maupun prestasi belajar mahasiswa.

Sebaliknya Bonney, Amoah, Micah, Ahiamenyo, \& Lemaire (2015) kompetensi yang dimiliki dosen tidak berpengaruh pada prestasi mahasiswa di Ghana, serta penelitian Murti \& Prasetio (2018) bahwa kompetensi akademik dan professional yang dimiliki dosen tidak berpengaruh terhadap prestasi belajar.

Kosgei, Mise, Odera, \& Ayugi (2013), dalam penelitiannya membuktikan tidak terdapat hubungan secara signifikkan antara kompetensi dosen dan prestasi belajar akademik mahasiswa di Kenya. Sejalan dengan penelitian Al-mutairi (2011) menunjukan bahwa tidak menemukan adanya hubungan antar kedua variabel pada mahasiswa di Kuwait. Kontradiksi antara kompetensi dosen dengan prestasi belajar menarik untuk dikaji lebih lanjut.

Prestasi belajar menurut Syah (2013) adalah suatu ukuran keberhasilan mahasiswa selama proses belajar yang dapat berupa skala angka maupun skala huruf. Muzenda (2013) penilaian prestasi mahasiwa dapat menggunakan pendekatan rata-rata nilai mata kuliah selama satu semester atau disebut dengan nilai IPK. Hal ini menjelaskan bahwa sangatlah penting mendapatkan nilai IPK yang tinggi karena sebagai tolok ukur keberhasilan selama proses belajar di perguruan tinggi antara mahasiswa dengan dosen yang bertugas mentransfer ilmunya, oleh karenanya dosen dituntut memiliki kompetensi yang tinggi.

Selain dari faktor eksternal yakni kompetensi dosen, prestasi belajar juga dipengaruhi oleh faktor internal, yakni motivasi Yamin (2013) menyatakan bahwa motivasi dapat 
menggerakkan psikis dari dalam diri supaya dapat melakukan kegiatan yang positif bagi idividu. Diperkuat dengan penelitian yang dilakukan oleh Cynthia, Martono, \& Indriayu (2016); Murtiningsih (2017) dan Rivaldo (2017) yang menghasilkan bahwa motivasi berpengaruh positif terhadap prestasi belajar. Uno (2008) indikator motivasi belajar dapat diukur berdasarkan 1)kemauan dalam belajar 2)teguh dalam pendirian 3)minat dan ketajaman dalam belajar 4)mandiri dalam belajar 5)berprestasi dalam belajar.

Berdasarkan studi pendahuluan yang dilakukan peneliti pada mahasiswa jurusan pendidikan ekonomi angkatan 2017 Universitas Negeri Surabaya didapati adanya keberagaman nilai hasil prestasi belajar, terdapat $41 \%$ dari 167 mahasiswa belum mampu mencapai IPK dengan predikat cumlaude seperti yang diharapakan. Alasan di pilihnya responden mahasiswa jurusan pendidikan ekonomi angkatan 2017 dikarenakan mahasiswa angkatan 2017 sudah memasuki tahap semester 5 dengan jumlah sks lebih banyak serta lebih banyak bertatap muka dengan dosen sehingga dapat dijadikan kriteria untuk meganalisis pengaruh kompetensi dosen terhadap prestasi belajar dari presepsi mahasiswa.

Berdasarkan pemaparan diatas dapat disimpulkan tujuan penelitian ini untuk mengetahui pengaruh kompetensi dosen sebagai faktor ekternal dan moteivasi belajar sebagai faktor internal terhadap prestasi belajar mahasiswa, serta adanya kontradiksi penelitian yang menunjukkan hasil penelitian berbeda pada variabel kompetensi dosen yang menarik untuk diteliti lebih lanjut. Perbedaan penelitian ini dengan penelitian sebelumnya yakni cakupan pada dimensi indikator variabel kompetensi dosen yang lebih luas meliputi keseluruhan empat kompetensi dosen sesuai dengan (Undang-Undang Republik Indonesia Nomor 14 Tahun 2005 Tentang Guru dan Dosen) yakni kompetensi pedagogik, kompetensi sosial, kompetensi kepribadian dan kompetensi professional, untuk menjawab adanya kontradiksi penelitian yang menunjukkan hasil penelitian berbeda pada variabel kompetensi dosen yang menarik untuk diteliti lebih lanjut.

\section{METODE}

Pada penelitian ini kriteria penilaian untuk variabel kompetensi dosen diperoleh dari jumlah hasil skala kuisioner yang menggunakan skala likert dengan kategori sangat baik, baik, cukup baik, tidak baik, dan sangat tidak baik. Sedangkan kriteria penilaian untuk variabel motivasi belajar menggunakan metode kuisiner oleh Hidayat (2009) dengan kategori motivasi kuat sebesar 67-100\%, motivasi sedang sebesar 34-66\% dan motivasi lemah sebesar 0-33\%.

Indikator variabel kompetensi dosen yang digunakan dalam penelitian bersumber pada (Undang-Undang
Republik Indonesia Nomor 14 Tahun 2005 Tentang Guru dan Dosen) yakni kompetensi pedagogik, kompetensi sosial, kompetensi kepribadian dan kompetensi professional. Indikator motivasi belajar bersumber dari Uno (2008) yakni 1)kemauan dalam belajar 2)teguh dalam pendirian 3)minat dan ketajaman dalam belajar 4)mandiri dalam belajar 5)berprestasi dalam belajar.

Penelitian ini menggunakan analisis regresi berganda linier yang bertujuan untuk mengetahui adanya pengaruh antara dua variabel bebas terhadap variabel terikat, dimana untuk mencari pengaruh variabel independen motivasi belajar (X1), kompetensi dosen (X2), terhadap variabel dependen prestasi belajar (Y), selanjutnya digambarkan sebagai berikut:

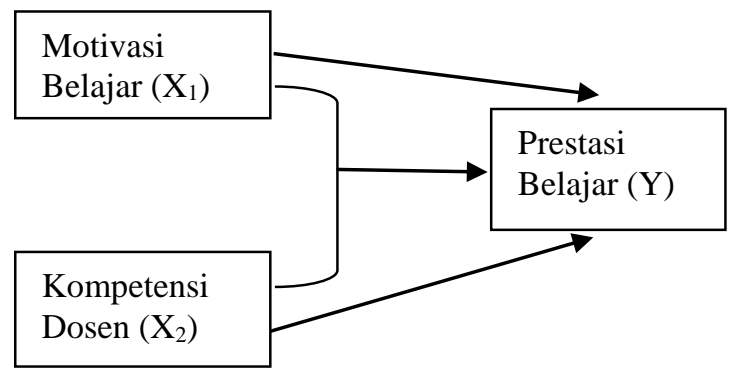

Gambar 1. Rancangan Penelitian

Populasi penelitian ini yakni mahasiswa aktif jurusan pendidikan ekonomi angkatan 2016 Universitas Negeri Surabaya yang berjumlah 317. Pengambilan sampel menggunakan metode Probability sampling dengan teknik Proportionate Stratified Random Sampling dan Simple Random Sampling. Dalam tabel Isaac dan Michael apabila populasi 320, tingkat kesalahan 5\% maka didapat sampel 167 responden.

Teknik pengumpulan data menggunakan metode kuisioner yang ditunjukkan kepada mahasiswa jurusan pendidikan ekonomi angkatan 2017 yang diisi melalui google formulir. Sedangkan dokumentasi diperlukan untuk mendapatkan data prestasi belajar mahasiswa (IPK), diperoleh dari TU jurusan. Skala untuk pengukuran instrument kuisioner yakni menggunakan skala likert.

Transformasi data perlu dilakukan untuk mengubah skala pengukuran data memiliki distribusi yang diharapkan. Data yang dihasilkan dari penelitian ini berupa data ordinal. Sedangkan untuk melakukan proses berikutnya dibutuhkan data interval. Sehingga peneliti mengubah data ordinal menjadi data. interval. dengan cara melakukan transfomasi data skor ke data skala menggunakan aplikasi soland.

Teknik analisis yakni statistik parametris karena data yang dihasilkan merupakan data interval dengan terlebih dahulu dilakukan analisis uji prasyarat regresi yakni uji asumsi klasik untuk memenuhi kriteri BLUE (Blue Linier Unbiased Estimator). Uji hipotesis perlu dilakukan untuk 
mengetahui pengaruh variabel bebas terhadap variabel terikat baik secara parsial serta simultan mengguakan uji $\mathrm{F}$ dan uji t statistik menggunakan bantuan aplikasi spss.

\section{HASIL DAN PEMBAHASAN}

Data diperoleh melalui penyebaran kuisioner melalui google formulir yang disebarkan kepada responden, kuisioner yang disebar memuat instrument penelitian mengenai indikator variabel motivasi belajar dan indikator kompetensi dosen menggunakan skala likert skor 1 sampai 5. Jumlah butir soal terdiri dari 24 butir variabel motivasi belajar dan 25 butir soal variabel kompetensi dosen yang telah lolos uji validitas dan reabilitas sedangkan data variabel prestasi belajar diperoleh dari Tu jurusan yakni nilai IPK semester 5 mahasiswa jurusan pendidikan ekonomi 2017.

Data kuisioner yang diperoleh tersebut kemudian ditransformasikan terlebih dahulu menggunakan aplikasi soland dan dilakukan uji prasyarat asumsi klasik yakni uji normalitas dengan metode statistik non-parametrik Kolmogorov - Smirnov, yang dinyatakan lolos uji apabila nilai Asymp Sig > (0.05). Hasil uji normalitas menunujukkan nilai Asymp Sig. sebesar 0.082 >0.05 maka pada model regresi nilai residual berditribusi normal.

Uji multikolinieritas. pada penelitian ini menggunakan teknik pengujian dari nilai Tolerance (TOL) dan Variance Inflation Factor (VIF) yang menghasilkan nilai VIF sebesar $1.058<10$ dan nilai TOL sebesar 0.945 sehingga dapat disimpulkan lolos uji multikolinieritas. Uji heteroskedastisitas menggunakan metode gletser menunjukkan menunjukkan bahwa untuk variabel motivasi belajar memiliki nilai Sig. $0.214>0.05$ sedangkan nilai Sig. variabel kompetensi dosen $0.958>0.05$ dari kedua nilai model regresi terbebas gejala heteroskedastisitas.

Uji linieritas dapat dilihat dengan mencari nilai Defiation From Linearity melalui $F$ tabel. Hasil menunjukkan deviatin from linieraity variabel motivasi belajar $0.281>0.05$, maka variabel motivasi belajar berhubungan secara linier terhadap variabel prestasi belajar. Sedangkan variabel kompetensi dosen sebesar 0.5 > 0.05 maka variabel kompetensi dosen berhubungan secara linier terhadap variabel prestasi belajar. Selanjutnya data dari kuisioner diolah menggunakan aplikasi spss untuk mengetahui nilai regresi linier berganda yang didapati hasil sebagai berikut:

Tabel 1. Hasil Uji T

\begin{tabular}{|c|c|c|c|c|c|}
\hline \multirow[b]{2}{*}{ Model } & $\begin{array}{l}\text { Unstandardized } \\
\text { Coefficients }\end{array}$ & \multicolumn{2}{|c|}{$\begin{array}{l}\text { Standardized } \\
\text { Coefficients }\end{array}$} & \multirow[b]{2}{*}{$\mathrm{T}$} & \multirow[b]{2}{*}{ Sig } \\
\hline & B & Std. Error & Beta & & \\
\hline (Constant) & 2.725 & .139 & & 19.582 & 0.000 \\
\hline Motivasi Belajar & .005 & .001 & .295 & 4.034 & 0.000 \\
\hline Kompetensi Dos & n. .004 & .001 & .228 & 3.124 & 0.000 \\
\hline
\end{tabular}

Sumber: Diolah peneliti, (2020).

Dari tabel regresi liner berganda diatas diperoleh persamaan regresinya $\mathrm{Y}=2.725+0.005 \times 1+0.004 \times 2+\mathrm{e}$. Hasil menunjukkan nilai konstanta dari variabel prestasi belajar sebesar 2.725. Nilai koefisien regresi variabel motivasi belajar 0.005 serta nilai koefisien dari variabel kompetensi dosen 0.004. Berdasarkan uji koefisien determinasi diketahui nilai adj R-Square 0.515 dengan tujuan mengurangi bias dari penambahan sampel maupun variabel, maka dapat disimpulkan bahwa variabel motivasi belajar dan kompetensi dosen dapat mempengaruhi prestasi belajar mahasiswa jurusan pendidikan ekonomi 2017 sebesar $51.5 \%$ sedangkan sisanya sebesar $48.5 \%$ dipengaruhi oleh. variabel diluar penelitian.

Untuk mengetahui seberapa besar pengaruh antar variabel secara maka perlu dilakukan uji t yang dapat dilihat pada tabel diatas menunjukkan nilai uji t hitung untuk variabel motivasi belajar sebesar 4.034 dengan nilai signifikansi sebesar 0.000 sedangkan nilai uji t hitung untuk varibel kompetensi dosen sebesar 3.124 dengan nilai signifikansi sebesar 0.014. Selanjutnya uji F dilakukan untuk mengetahui besaran pengaruh secara simultan variabel bebas terhadap variabel terikat. Berikut ini hasil uji $\mathrm{F}$ yang diolah menggunakan progam aplikasi spss.

Tabel 2. Hasil Uji F.

\begin{tabular}{llcccc}
\hline Model & $\begin{array}{l}\text { Sum of } \\
\text { Squares }\end{array}$ & df & Mean Square & F & Sig. \\
\hline Regeression & 0.442 & 2 & 0.221 & 16.887 & $0.000^{\mathrm{a}}$ \\
\hline Residual & 2.146 & 164 & 0.013 & & \\
\hline Total & 2.588 & 166 & & & \\
\hline
\end{tabular}

Sumber: Diolah peneliti, (2020).

Berdasarkan hasil Uji F, dengan nilai sig sebesar 0.000 $<$ 0.05. maka kompetensi dosen dan motivasi belajar secara simultan berpengaruh terhadap variabel prestasi belajar secara signifikan pada mahasiswa jurusan pendidikan ekonomi 2017.

\section{Pengaruh Kompetensi Dosen Terhadap Prestasi Belajar}

Didapatkan fakta bahwa adanya pengaruh yang posistif dan signifikkan terhadap prestasi belajar mahasiswa dengan nilai dari uji t sebesar 3.124 dengan nilai sig. 0.014 < 0.05 Dari hasil kuisioner yang berdasarkan presepsi mahasiswa saja tentang variabel kompetensi yang dimiliki dosen dapat diketahui 41,32 \% mahasiswa menyatakan dalam kondisi baik serta sisanya 58,68\% dalam kondisi cukup baik. Pengaruh ini berisfat positif yang artinya apabila kompetensi dosen meningkat atau berkembang maka prestasi belajar mahasiswa akan meningkat, berlaku juga sebaliknya. 
Hal Ini sesuai dengan pendapat Danim (2008) kompetensi yang dimiliki dosen tentunya memiliki pengaruh terhadap mahasiswa, proses pembelajaran akan tercapai secara optimal apabila dosen yang bertugas sebagai transfer ilmu memilki kompetensi yang baik. Berkembangnya kompetensi dosen akan sangat membantu mahasiswa meraih prestasi belajar yang tinggi, hal ini terbukti dari kompetensi dosen yang digunakan selama proses pembelajaran maupun tidak dalam proses pembelajaran.

Kompetensi dosen tersebut meliputi 1)kompetensi pedagogik meliputi kemampuan mengelola pembelajaran 2)kompetensi kepribadian meliputi sikap dan tindakan dosen selama proses pembelajaran berlangsung 3)kompetensi sosial meliputi kemampuan interaksi komunikasi 4) kompetensi professional yang meliputi penguasaan materi serta menyebarluaskan inovasi dalam bidang ilmu pengetahuan.

Dalam proses belajar mengajar interksi antar dosen dan mahasiswa merupakan hal yang sangat penting karena tidak hanya mahasiswa saja yang memperoleh manfaat, namun juga dosen memperoleh umpan balik apakah transfer ilmu dapat diterima mahasiswa dengan baik. Ganyaupfu (2014) menjelaskan kompetensi dosen merupakan gambaran keberhasilan yang tercipta dari adanya interksi antar dosen dan mahasiswa baik saat proses belajar maupaun tidak dalam proses belajar, serta ukuran keberhasilan terlihat dari hasil prestasi belajar yang dicapai.

Hal ini membuktikan dengan adanya kompetensi dosen yang baik tentunya dapat menjadi faktor eksternal untuk meningkatkan prestasi belajar mahasiswa. Sesuai dengan penelitian yang dilakukan oleh beberapa ahli seperti Mediawati (2010); Ganyaupfu (2014); Muzenda (2013); Astuty (2015); Yousef (2018); Gee (2018) dan Alam (2018).

\section{Pengaruh Motivasi Belajar Terhadap Prestasi Belajar}

Berdasarkan hasil analisis regeresi liner berganda, didapatkan fakta bahwa adanya pengaruh posistif dan signifikkan dengan nilai t sebesar 4.034 dengan nilai sig $0.00<0.05$ terhadap prestasi belajar mahasiswa jurusan pendidikan ekonomi. Motivasi menjadi faktor penting yang mendorong dari dalam diri individu sendiri yang digunakan selama proses belajar. Berdasarkan hasil rekapitulasi kuisioner variabel motivasi belajar dapat diketahui 68,86\% mahasiswa jurusan pendidikan ekonomi 2017 dalam kondisi memiliki motivasi kuat. Meskipun 59\% mahasiswa jurusan pendidikian ekonomi 2017 mampu mencapai prestasi belajar dengan IPK skala cumlaued, namun tentunya dengan meningkatkan motivasi belajar mahasiswa akan berdampak lebih terhadap meningkatknya prestasi belajar dan sebaliknya.
Motivasi belajar merupakan faktor penting dari sisi internal yang dapat meningkatkan prestasi belajar karena dengan mahasiswa memacu motivasi belajar harapannya dapat menggerakkan mahasiswa sendiri untuk lebih semangat dalam kegiatan belajar mengajar sehingga dapat terpacu untuk meraih prestasi belajar yang tinggi sesuai dengan teori belajar kontruktivisme Slameto (2013).

Mahasiswa dapat dikatakan memiliki motivasi tinggi apabila memiliki indikator seperti 1)tekun dalam belajar meliputi keseriusan dalam belajar yang bertujuan untuk meraih prestasi yang sebaik-baiknya 2)ulet dalam menghadapi kesulitan belajar meliputi sikap tidak mudah menyerah 3)minat dan ketajaman dalam belajar meliputi keinginan kuat untuk belajar lebih giat 4)berprestasi dalam belajar meliputi pencapaian hasil maksimal selama kegiatan belajar 5)mandiri dalam belajar meliputi sikap individu tidak bergantung pada orang lain selama proses belajar.

Motivasi belajar memiliki pengaruh positif yang artinya semakin meningkatnya motivasi belajar dalam diri mahasiswa maka akan meningkatkan prestasi belajar, berlaku juga sebaliknya apabila menurunnya tingkat motivasi belajar yang dimiliki mahasiswa akan berpengaruh menurunnya prestasi belajar. Sejalan dengan penelitian Cynthia, Martono \& Indriayu (2016); Murtiningsih (2017) dan Rivaldo (2017).

\section{Pengaruh Kompetensi Dosen dan Motivasi Belajar Terhadap Prestasi Belajar}

Berdasarkan hasil analisis uji $\mathrm{F}$ dengan hasil sig. sebesar $0.000<0.05$, disimpulkan bahwa variabel motivasi belajar dan kompetensi dosen berpengaruh signifikan secara simultan terhadap prestasi belajar sebesar $51.5 \%$ dan sisanya dipengaruhi oleh faktor-faktor lain yang tidak diteliti dalam penelitian. Pengaruh motivasi belajar dan kompetensi dosen pada penelitian ini bersifat positif dan signifikan yang artinya apabila motivasi belajar dan kompetensi dosen tinggi maka prestasi belajar mahasiswa juga tinggi.

Dalam penelitian yang dilakukan pada mahasiswa jurusan pendidikan ekonomi 2017 Universitas Negeri Surabaya didapati adanya keseimbangan antar kedua faktor yang mempengaruhi prestasi belajar. Hasilnya kompetensi yang dimiliki dosen dalam kondisi baik berdasarkan presepsi mahasiswa dan motivasi belajar yang dimiliki mahasiswa juga dalam kondisi baik, sehingga pada penelitian ini kedua variabel berpengaruh secara signifikan terhadap prestasi belajar yang dicapai mahasiswa.

Prestasi belajar dapat tercapai secara optimal apabila kedua variabel dalam kondisi yang baik karena keduanya saling melengkapi dari sisi internal yakni motivasi belajar dan sisi eksternal yakni kompetensi dosen. Apabila mahasiswa hanya memiliki motivasi belajar yang tinggi 
namun tidak adanya kompetensi dosen yang baik selama proses pembelajaran maka mahasiswa akan kesulitan selama proses belajar. Sebaliknya jika kompetensi dosen sudah dikatakan baik namun mahasiswa sendiri tidak memiliki motivasi belajar yang tinggi maka mahasiwa tidak mampu meraih prestasi yang tinggi. Kedua variabel sangat penting untuk meningkatkan prestasi belajar sesuai dengan penelitian Astuty (2015) dan Yousef (2018).

\section{SIMPULAN}

Berdasarkan hasil analisis data yang telah dilakukan, diperoleh informasi bahwa variabel kompetensi dosen dan motivasi belajar berpengaruh signifikan terhadap prestasi belajar mahasiswa baik parsial maupun simultan. Besaran kontribusi pengaruh kedua variabel sebesar $51.5 \%$, sedangkan sisanya dipengaruhi oleh variabel diluar penelitian. Variabel kompetensi dosen dan variabel motivasi belajar berpengaruh terhadap pencapaian prestasi belajar (IPK) Indek Prestasi Kumulatif pada mahasiswa jurusan pendidikan ekonomi angkatan 2017 Universitas Negeri Surabaya.

Perlu dilakukan penelitian selanjutnya untuk menambahkan faktor lain yang dapat berpengaruh untuk meningkatkan prestasi belajar mahasiswa baik seperti fasilitas belajar, gaya belajar, lingkungan belajar dan variabel lainnya. Serta keterbatasan pada variabel kompetensi dosen yang hanya dari sudut pandang persepsi mahasiwa saja, untuk nantinya dapat dikembangkan dari presepsi dosen dan presepsi mahasiwa sehingga terjadi keseimbangan presepsi sehingga tidak terjadi kontradiksi penelitian.

\section{DAFTAR PUSTAKA}

Al-mutairi, A. (2011). Factors Affecting Business Students 'Performance in Arab Open University: The Case of Kuwait. International Journal of Business and Mangement, 6(5), 146-155. https://doi.org/10.5539/ijbm.v6n5p146

Alam, Y. (2018). Kompetensi Dosen, Motivasi Belajar Mahasiswa dan Dampaknya terhadap Prestasi Mahasiswa dalam Pembelajaran Pengantar Ekonomi ( studi pada mahasiswa program studi Manajemen Informatika AMIK Bina Sriwijaya Palembang ). Jurnal Manajemen Dan Bisnis Sriwijaya, 16(4). Retrieved from http://ejournal.unsri.ac.id/index.php/jmbs

Astuty, E. (2015). Implementation Analysis of Lecturer's Pedagogical Competence on Student's Academic Achievement. Journal of Management Research, 7(2), 152. https://doi.org/10.5296/jmr.v7i2.6834

Bonney, E. A., Amoah, D. F., Micah, S. A., Ahiamenyo, C., \& Lemaire, M. B. (2015). The Relationship between the Quality of Teachers and Pupils Academic Performance in the STMA Junior High Schools of the Western Region of Ghana. Journal of
Education and Practice, 6(24).

Cynthia, L. C., Martono, T., \& Indriayu, M. (2016). Pengaruh Fasilitas Belajar dan Motivasi Belajar Terhadap Prestasi Belajar Mata Pelajaran Ekonomi Siswa Kelas XI IIS di SMA Negeri 5 Surakarta Tahun Ajaran 2015/2016. Jurnal Pendidikan Bisnis Dan Ekonomi, 01(02), 1-20. Retrieved from http://jurnal.fkip.uns.ac.id/index.php/ptn/article/vie w/7397/5169

Danim, S. (2010). Profesionalisasi dan etika profesi guru. Bandung: Alfabeta.

Ganyaupfu, E. M. (2014). Factors Influencing Academic Achievement in Quantitative Courses among Business Students of Private Higher Education Institutions Factors Influencing Academic Achievement in Quantitative Courses among Business Students of Private Higher Education Institut. (July).

Gee, N. C. (2018). The Impact of Lecturers , Competencies on Students' Satisfaction. Journal of Arts and Social Sciences, 1(2), 74-86.

Hidayat. (2009). Metodelogi Penelitian Kesehatan. Jakarta: Bhineka Cipta.

Kosgei, A., Mise, J. K., Odera, O., \& Ayugi, M. E. (2013). Influence of teacher characteristics on students , academic achievement among secondary schools. Journal of Education and Practice, 4(3), 76-82.

Mediawati, E. (2010). Pengaruh Motivasi Belajar Mahasiswa Dan Kompetensi Dosen Terhadap Prestasi Belajar. Journal Pendidikan Ekonomi Dinamika Pendidikan, 5(2), 134-146. https://doi.org/10.15294/dp.v5i2.4922

Murti, R. W., \& Prasetio, A. P. (2018). Pengaruh Kompetensi Dosen terhadap Prestasi Akademik Mahasiswa Fakultas Ekonomi dan Bisnis Telkom University Influence of Lecturers ' Competence to Student's Academic Achievement of Faculty Economics nnd Business Telkom University. Jurnal Penelitian Pendidikan.

Murtiningsih. (2017). Pengaruh Motivasi Belajar Sarana Belajar dan Percaya Diri Terhadap Hasil Belajar IPS Siswa Penerima BSM (Bantuan Siswa Miskin) SMP Negeri Di Surabaya. Jurnal Ekonomi Pendidikan Dan Kewirausahaan, 5(2). Retrieved from https://journal.unesa.ac.id/index.php/jepk

Muzenda, A. (2013). Lecturer s' Competences and Students 'Academic Performance. International Journal of Humanities and Social Science Invention, 3(1), 6-13.

Olaitan, A. W. (2018). Effects Of Perceived Lecturers' Competence And Classroom Environment On Students' Academic Performance Akinleke W. Olaitan Department of General Studies, Federal Polytechnic, P.M.B. 50, Ilaro, Ogun State, Nigeria. Department of General Studies, Federal Polytechnic, P.M.B. 50, Ilaro, Ogun State, Nigeria, 6(5), 68-77.

Rivaldo, Y. (2017). Pengaruh Fasilitas Belajar, Kebiasaan Belajar, dan Motivasi Belajar Terhadap Prestasi Belajar Mahasiswa Program Studi Ekonomi pada STKIP PGRI Sumbar. E-Journal Padang. 
Sadirman, A. M. (2020). Interaksi dan Motivasi Belajar Mengajar. https://doi.org/10.26740/jepk.v5n2.p178-191

Simamora, B. (2014). Pengaruh Disiplin dan Kompetensi Dosen Terhadap Prestasi Mahasiswa Progam Studi Penerbitan. Journal Publipreneur, 2(4).

Slameto. (2010). Belajar dan Faktor-Faktor Yang Mempengaruhinya. Bina Aksara.

Syah, M. (2013). Psikologi Pendidikan Dengan Pendekatan Baru. Bandung: Bandung PT Remaja Rosdakarya.

Undang-Undang Republik Indonesia Nomor 14 Tahun 2005 Tentang Guru dan Dosen. (n.d.).

Uno, H. B. (2008). Teori Motivasi dan Pengukurannya. Jakarta: Bumi Aksara.

Wamala, R. (2013). Teacher Competence And The Academic Achievement Of Sixth Grade Students In Uganda. Journal of International Education Research, 9(1), 83-90. Retrieved from http://www.cluteinstitute.com

Yamin, M. (2013). Strategi dan Metode dalam Model Inovasi Pembelajaran. Jakarta: Gaung Persada Press group.

Yousef, D. A. (2018). Factors Influencing Academic Performance in Quantitative Courses among Undergraduate Business Students of a Public Higher Education Institution Journal of International Education in Business Article information: Journal of International Education in Business, 10(March), 12-30. https://doi.org/10.1108/JIEB-07-2016-0016 